\title{
Isotopic labeling and antifungal resistance as tracers of gut passage of the sea fan pathogen Aspergillus sydowii
}

\author{
Krystal L. Rypien ${ }^{1,2, *}$, David M. Baker ${ }^{1}$ \\ ${ }^{1}$ Department of Ecology and Evolutionary Biology, Dale R. Corson Hall, Cornell University, Ithaca, New York 14853, USA \\ ${ }^{2}$ Present address: Scripps Institution of Oceanography, Marine Biology Research Division, 9500 Gilman Drive MC 0202, La \\ Jolla, California 92093, USA
}

\begin{abstract}
Vectors play a critical role in the ecology of infectious disease by facilitating betweenhost transmission, emphasizing the multi-species nature of disease. Corals are suffering an onslaught of infectious diseases, yet we know little about the role of vector species in the ecology of these epizootics. The infection of octocorals by the fungus Aspergillus sydowii is a widespread Caribbean coral disease. The snail Cyphoma gibbosum is a likely vector species because it is a specialist predator of octocorals, moves regularly among coral colonies, and aggregates on diseased corals. We used a novel application of stable isotope techniques and antifungal-resistant strains of A. sydowii to identify the potential for this snail to vector disease. The use of both isotopically labeled and hygromycinresistant fungus was successful in definitively tracing A. sydowii through the guts of C. gibbosum from ingestion to feces. Further, we demonstrated in laboratory experiments that snails fed antifungal-resistant A. sydowii excrete viable spores and hyphae in their feces. Overall, this study demonstrates the usefulness of isotopic labeling and antifungal-resistant fungi to trace the movement of pathogen propagules in microbially diverse environments, and suggests that $C$. gibbosum may be able to spread aspergillosis between octocoral hosts.
\end{abstract}

KEY WORDS: Coral disease ' Isotope label ' Hygromycin resistance Flamingo tongue snail Gut passage $\cdot$ Corallivore $\cdot$ Specialist predator $\cdot$ Aspergillus sydowii $\cdot \delta^{15} \mathrm{~N}$

\section{INTRODUCTION}

Infectious disease rarely involves just pathogen and host. Rather, networks of species interact with the pathogen either directly through vector-based transmission and multiple host species, or indirectly through disease-mediated effects on community structure and function (Antonovics et al. 1995, Dobson 2004, Hatcher et al. 2006, Keesing et al. 2006). Vectors are a critical component of the network of species interacting with infectious diseases because of their influence on the epidemiological cycle. Vector-borne diseases are often highly virulent, due to the increase in transmission efficiency they afford (Ewald 1983), and transmission is generally frequency-dependent (Antonovics et al. 1995), which alters the impact of species diversity on disease dynamics (Dobson 2004, Keesing et al.
2006). Vector biology can also interact with environmental changes to influence disease dynamics; for example, climate change and globalization can alter the distribution and life cycle duration of vectors (Harvell et al. 2002, Anderson et al. 2004).

In contrast to well-known vector dynamics on land, vectors of marine diseases are comparatively rare (McCallum et al. 2003). However, this could be the result of insufficient study rather than a genuine pattern. With the recent increase in the number and severity of marine epidemics (Harvell et al. 2004, Ward \& Lafferty 2004), identifying marine diseases where vectors play a role is critical to management. This is especially true for diseases infecting a sessile host, where the presence of vectors could dramatically increase the rate of disease spread (McCallum et al. 2003). 
Corals are vulnerable to emergent disease due to the numerous environmental stressors placed upon the coral holobiont (Hoegh-Guldberg 1999, Gardner et al. 2003, Hughes et al. 2003, Harvell et al. 2007), as well as their proximity to coastal pathogen sources (Patterson et al. 2002). Several coral diseases have vectors that contribute to, but are not entirely responsible for, disease spread. These vectors are almost exclusively coral predators that inadvertently ingest pathogens and spread them during feeding movements. Corallivorous snails have been identified as vectors of an unknown disease in Caribbean acroporid corals (Williams \& Miller 2005), and have been associated with coral disease outbreaks in the Red Sea (Antonius \& Riegl 1997). In the Mediterranean, the predatory polychaete Hermodice carunculata is a vector and reservoir of the coral pathogen Vibrio shiloi (Sussman et al. 2003). While these vectors are not the sole mechanism of transmission, positive feedback due to injury from predation and aggregative feeding behavior suggest that they play a critical role in the ecology of these coral diseases.

Aspergillosis is a fungal disease of Caribbean octocorals caused by Aspergillus sydowii. This disease was first observed in the early 1990s (Nagelkerken et al. $1997 a, b)$ and infects at least 8 different species of octocorals (Smith \& Weil 2004), the dominant group on many Caribbean reefs (Opresko 1973). Specialist predators, such as the snail Cyphoma gibbosum, that are dependent on octocorals for habitat, food, and oviposition sites, are a group that will likely suffer the effects of aspergillosis. C. gibbosum is common on many Caribbean reefs, and makes regular mate- and food-searching movements (Nowlis 1993), with snails moving among corals on average every $3 \mathrm{~d}$ (K. Rypien unpubl.). Although C. gibbosum will eat most octocoral species, it does demonstrate distinct host preferences. The most common preferred genera include Eunicea, Plexaura, Pseudopterogorgia, and Gorgonia (Birkeland \& Gregory 1975, Harvell \& Suchanek 1987, Lasker \& Coffroth 1988, Lasker et al. 1988, Chiappone et al. 2003, K. Rypien unpubl.).

Observations of increased density of Cyphoma gibbosum on diseased sea fans (Nagelkerken et al. 1997a, Slattery 1999), and the overlap between preferred octocoral species and those infected by Aspergillus sydowii (Smith \& Weil 2004), suggest that aspergillosis may affect non-host species by altering the distribution of predators. Although the mode of transmission of aspergillosis is unknown, an analysis of spatial patterns of disease suggests that direct contact is not the sole mechanism of transmission, and secondary mechanisms such as vectors may facilitate spread at locations with high disease prevalence (Jolles et al. 2002). Thus, C. gibbosum is a key link in the disease ecology of aspergillosis, as it is likely influenced by disease through the removal of its coral prey, and may in turn influence between-host transmission of aspergillosis by acting as a vector.

Marine environments are microbially diverse, making the study of a single species or strain of pathogen challenging. Previous studies tracing the gut passage of pathogens often relied on direct culturing or molecular identification (Dromph 2001, Colgan \& Claridge 2002, Meier et al. 2002, Lilleskov \& Bruns 2005), both of which are ineffective for cosmopolitan species such as Aspergillus sydowii, which is a common indoor air contaminant (Klich 2002). Here we investigated 2 methods for tracing pathogen propagules through the environment: the use of isotopically labeled or hygromycin-resistant $A$. sydowii. The ecological likelihood of snails feeding on diseased corals was assessed using a choice-feeding assay, where snails were offered artificial food amended with crude organic extracts from diseased and healthy corals. The results of these studies demonstrate the utility of these methods to track the passage and viability of ingested fungus, and indicate that Cyphoma gibbosum may be a vector of aspergillosis.

\section{MATERIALS AND METHODS}

Food choice experiment. Sixteen adult $(>2.5 \mathrm{~cm})$ Cyphoma gibbosum were collected from North Norman's Reef (2347' 386" N, 7608' 273" W), Bahamas. Snails were maintained in individual cages $(14 \times 14 \times$ $14 \mathrm{~cm}$ ) in a flow-through natural seawater system at the Perry Institute for Marine Science, Caribbean Marine Research Center. Snails were acclimated and starved for $4 \mathrm{~d}$ prior to experimentation.

Artificial food consisted of $2.5 \%$ carrageenan and $12.5 \%$ feeding attractant $(10 \mathrm{~cm}$ fragment of homogenized Eunicea flexuosa [formerly Plexaura flexuosa, Grajales et al. 2007], a preferred food source; Harvell \& Suchanek 1987, Lasker \& Coffroth 1988, Lasker et al. 1988, Chiappone et al. 2003) in $10 \mathrm{ml}$ distilled water, and organic extracts from either healthy or diseased Gorgonia ventalina. Organic extracts were prepared by collecting fragments from $G$. ventalina colonies (10 healthy, 10 diseased), extracting twice in dichloromethane, evaporating the dichloromethane, and resuspending in a minimal amount of acetone. The extracts were added to the artificial food at naturally volumetric concentrations. The artificial food was poured into molds and cut into $3 \times 1 \times 0.2 \mathrm{~cm}$ pieces and weighed. Snails were given a block of food from each treatment spaced equidistantly in the cage. Once at least $50 \%$ of both blocks of food was consumed (approximately $20 \mathrm{~h}$ ), the food was removed, patted 
dry, and re-weighed. The proportion of food eaten was checked for normality and analyzed using a paired $t$ test with JMP 6.0.

Gut passage experiment. In June 2007, 22 adult $(>2.5 \mathrm{~cm})$ Cyphoma gibbosum were collected from reefs near Key Largo, Florida (USA), and shipped to Ithaca, New York (USA). There, the snails were acclimated without feeding in an artificial seawater system $\left(12: 12 \mathrm{~h}\right.$ light, temperature $\left.26.5^{\circ} \mathrm{C}\right)$ for $48 \mathrm{~h}$. Snails were housed in individual cages $(14 \times 14 \times 14 \mathrm{~cm})$ constructed from plastic containers with mesh panels to provide water exchange.

Snails were fed artificial food consisting of $3.5 \%$ carrageenan (Type I) and 16\% feeding attractant (a homogenized $20 \mathrm{~cm}$ fragment of Plexaura homomalla, a preferred octocoral; Harvell \& Suchanek 1987, Lasker \& Coffroth 1988, Lasker et al. 1988, Chiappone et al. 2003) in $10 \mathrm{ml}$ deionized water, and either ${ }^{15} \mathrm{~N}$ enriched or unenriched Aspergillus sydowii. The use of isotopically labeled A. sydowii allowed us to definitely track the movement of this pathogen through the guts of snails, without the problem of contamination by the diverse fungal community found in the environment.

The fungus was originally cultured from a diseased sea fan in Saba, Netherlands Antilles (Smith et al. 1996), and was grown on potato dextrose agar (PDA) amended with either $98 \%{ }^{15} \mathrm{~N}$-labeled sodium nitrate $\left(16 \mathrm{mg} \mathrm{l}^{-1}\right)$ or unenriched sodium nitrate. The fungus was grown at $25^{\circ} \mathrm{C}$ for $7 \mathrm{~d}$, after which the hyphae and spores were scraped from the surface, and re-suspended in a solution of phosphate buffered saline (10×) with $10 \%$ glycerol and $0.1 \%$ Tween 80 . This stock was stored at $-80^{\circ} \mathrm{C}$. The fungal mixture contained both spores and hyphae (approximately 10:1 ratio), and fungus was added to the artificial snail food to reach a final concentration of $2.0 \times 10^{6}$ spores $\mathrm{ml}^{-1}$. We confirmed that Aspergillus sydowii remained viable within the artificial food by analyzing the resulting fungal growth from food incubated at $25^{\circ} \mathrm{C}$ on PDA.

To make the artificial food, carrageenan was dissolved in distilled water and cooled while stirring. At a temperature just above solidifying, the feeding attractant and fungus were added, and the food was immediately poured into an acrylic mold $(30 \times 2 \times 0.3 \mathrm{~cm})$ lined with plastic window screen for support. Once solid, the food was cut into $2 \times 1 \times 0.3 \mathrm{~cm}$ blocks. To ensure that no contamination occurred between enriched and unenriched food, separate equipment and lab space was used for each treatment.

At the start of the experiment, each snail was given one block of artificial food. Every $48 \mathrm{~h}$, the food was removed, fecal pellets collected, and another block of freshly prepared artificial food was added to the cage. This was repeated a total of 4 times. Fecal pellets were stored at $4^{\circ} \mathrm{C}$ until the end of the experiment, when all the feces from a single snail were pooled and prepared for isotope analysis.

Stable isotope analysis. Feces were pooled by individual to obtain sufficient mass for isotope analysis, and were rinsed with deionized water and dried at $60^{\circ} \mathrm{C}$ for $24 \mathrm{~h}$. Samples of initial snail feces (produced from feeding on wild food sources), enriched and unenriched fungus, and enriched and unenriched artificial food were also dried at $60^{\circ} \mathrm{C}$. Three snails from each treatment were sacrificed for tissue isotope analysis to detect signs of digestion and assimilation of fungal-derived nitrogen, and were removed from their shells and dissected to remove the digestive tract. The remaining tissue was oven-dried at $60^{\circ} \mathrm{C}$ for $24 \mathrm{~h}$, frozen in liquid nitrogen, and homogenized using a mortar and pestle. All samples were stored in a desiccation chamber prior to analysis.

Samples were weighed (up to $3.0 \mathrm{mg}$ ) into $4 \times 6 \mathrm{~mm}$ tin capsules. Isotope values were determined by the Cornell University Stable Isotope Lab (COIL) using a Finnegan MAT Delta Plus isotope-ratio mass spectrometer coupled to a Carlo-Erba elemental analyzer via a Conflo II open-split interface (EA-IRMS). ${ }^{15} \mathrm{~N}$ labeled and natural abundance samples were analyzed in separate runs. Precision of an in-house standard $( \pm \mathrm{SD})$ for $\delta^{15} \mathrm{~N}$ was $\pm 0.046 \%$ and $\pm 0.068 \%$, respectively.

The ${ }^{13} \mathrm{C}$ content of samples was also analyzed to determine if the snails were digesting artificial food equally well in both treatments. Precision of $\delta^{13} \mathrm{C}$ for ${ }^{15} \mathrm{~N}$-labeled and natural abundance samples was \pm 0.031 and $\pm 0.041 \%$, respectively.

$\delta^{15} \mathrm{~N}$ and $\delta^{13} \mathrm{C}$ values of feces and tissue from initial, enriched fungus-fed, and unenriched treatments were compared using an analysis of variance (ANOVA). Student's $t$-test was used to conduct pair-wise comparisons of means. All statistical tests were performed using JMP 6.0.

Fungal viability. To assess fungal viability following gut passage, we used an isolate of Aspergillus sydowii genetically modified for hygromycin resistance (K. Kim unpubl.). This allowed us to quickly screen snail feces for A. sydowii, without the risk of overgrowth by other rapidly growing fungi present in the seawater or fecal pellets. Seven snails not used in the stable isotope experiment were fed artificial food containing either hygromycin-resistant $A$. sydowii spores and hyphae, or no fungus (control). Feces were collected, rinsed, and plated on PDA with $0.8 \mathrm{mg} \mathrm{ml}^{-1}$ hygromycin. Only feces from snails that consumed artificial food were examined. Samples of seawater $(1 \mathrm{ml})$ and other biotic substrates (filamentous algae) were placed on PDA as controls. The samples were incubated at $25^{\circ} \mathrm{C}$, and fungi were identified to genus using Domsch et al. 
(1980) and St. Germain \& Summerbell (1996). All Aspergillus spp. were identified to species using Klich (2002), which examines colony-level morphological characteristics (color, growth rate) and microscopic characteristics observed under standard light microscopy $\left(100 x_{i}\right.$ shape and color of conidia, sporulating structures [vesicles], and hyphae).

\section{RESULTS}

\section{Food choice and gut passage experiments}

Although not significant, there was a trend in the amount of artificial food consumed by Cyphoma gibbo$\operatorname{sum}(t=2.13, \mathrm{p}=0.0527)$, with snails eating more of the food amended with diseased gorgonian coral extracts (Fig. 1).

Preliminary analysis of fungus grown on enriched media confirmed assimilation of ${ }^{15} \mathrm{NO}_{3}{ }^{-}$in contrast to that grown on unenriched media (media $\delta^{15} \mathrm{~N}$ [labeled vs. non-labeled]: 1144.5 vs. $0.2 \%$; fungus $\delta^{15} \mathrm{~N}$ : $1671.3 \%$ vs. $0.6 \%$ ), demonstrating the effectiveness of the isotopic enrichment. However, there was no apparent difference between enriched and unenriched fungus with respect to $\delta^{13} \mathrm{C}$ (media $\delta^{13} \mathrm{C}$ : $-16.5 \%$ vs. $-16.0 \%$; fungus $\delta^{13} \mathrm{C}$ : $-14.7 \%$ vs. $-14.8 \%$ ). The viability of fungus added to artificial food was also confirmed by the growth of Aspergillus sydowii on all samples of fungus-containing food, and the absence of A. sydowii on all samples of fungus-free food.

During the course of the experiment, 3 snails died: 2 in the unenriched treatment and 1 in the enriched treatment. In addition, not all snails ingested sufficient quantities of artificial food to provide ample feces for

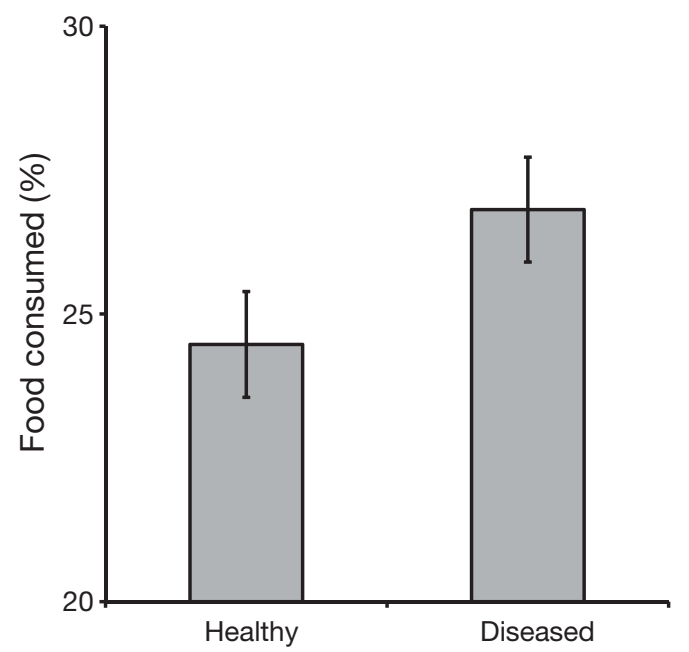

Fig. 1. Proportion of food containing extracts from healthy and diseased sea fans Gorgonia ventalina that was eaten by Cyphoma gibbosum $(\mathrm{N}=16)$ in a choice feeding assay (mean $\pm \mathrm{SE}$ ) isotope analysis. Thus, the final numbers of snails that could be used for analysis were 6 fed unenriched artificial food and 8 fed enriched food.

There was a significant effect of fungus treatment on fecal pellet $\delta^{15} \mathrm{~N}$ (Fig. 2; $F=55.08$, df $=2$, p $<0.0001$ ). Enriched fungus-fed snails produced feces with significantly higher $\delta^{15} \mathrm{~N}$ values than initial and unenriched treatments (on average 7.9 and $8.0 \%$ higher, respectively). However, $\delta^{15} \mathrm{~N}$ of snail tissue was not different between treatments (Fig. $2 ; t=-1.43$, df $=4, \mathrm{p}=0.224$ ), indicating that ingested fungus was not assimilated and was being passed through the snail gut.

There was a significant effect of treatment on fecal pellet $\delta^{13} \mathrm{C}(F=113.75$, df $=2, \mathrm{p}<0.0001)$. However, this difference was driven by initial (wild) feces, which were on average $13 \%$ more depleted than $\delta^{13} \mathrm{C}$ values from experimental feces. There was no significant difference between feces from enriched fungus-fed snails and unenriched fungus-fed snails $(t=0.54$, $\mathrm{df}=12, \mathrm{p}=$ $0.59)$, confirming that the snails were eating the artificial food equally in both treatments.

\section{Fungal viability}

The feces of 2 of 3 snails fed artificial food amended with hygromycin-resistant fungus grew Aspergillus sydowii, as confirmed using microscopic morphological features. None of the feces from 4 snails fed control (fungus-free) food grew A. sydowii. This suggests that it is possible for viable fungus to survive gut passage; however, the relative frequency of this occurring in situ is unknown.

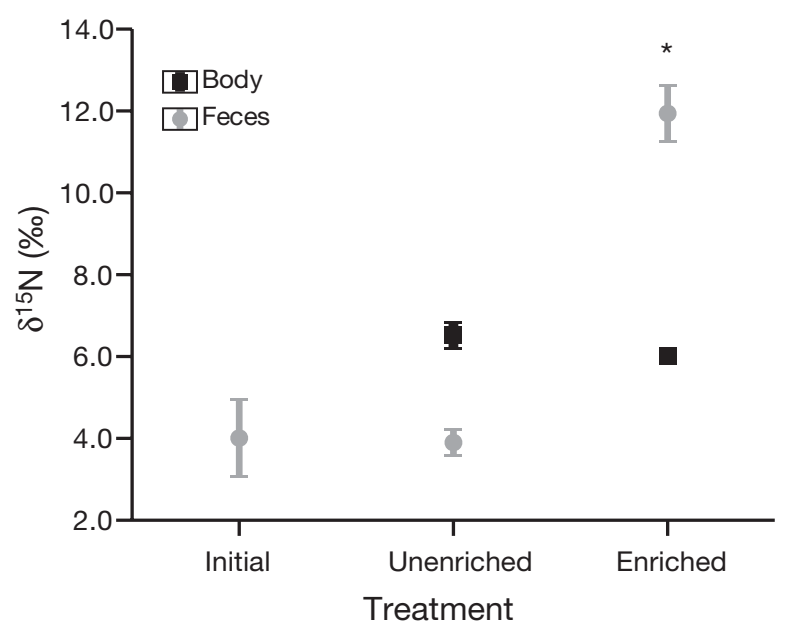

Fig. 2. Cyphoma gibbosum. $\delta^{15} \mathrm{~N}$ values (mean $\pm \mathrm{SE}$ ) of C. gibbosum body tissue (black squares) and feces (grey circles) prior to experimentation (initial), or following feeding on artificial food amended with either unenriched or enriched spores and hyphae of Aspergillus sydowii. *Significance within tissue type at $\alpha=0.05$ 


\section{DISCUSSION}

These experiments demonstrate that the use of either isotopically labeled or hygromycin-resistant Aspergillus sydowii is a successful method to track the movement of a single species of pathogen through an environment rich in fungal biota. In addition, we found that Cyphoma gibbosum can pass viable A. sydowii spores and hyphae in their fecal pellets. However, due to the small sample size in this experiment, the magnitude of fungal mortality due to ingestion remains unknown. These results suggest that snail predators can act as an important link in the disease ecology of aspergillosis.

Isotopically labeled fungus allowed us to track the movement of ingested Aspergillus sydowii into the feces of snails; snails fed isotopically enriched fungus had fecal pellets that were significantly enriched relative to feces from snails fed unenriched fungi (Fig. 2). Measurement of $\delta^{13} \mathrm{C}$ values also showed a drastic shift, decreasing by $13 \%$ once snails began feeding on artificial food, allowing us to confirm consumption of food in both treatments. Given that we pooled feces over the course of $8 \mathrm{~d}$, the amount of nitrogen from enriched fungus was diluted with other sources of fecal-derived nitrogen, representing a mixed pool of previously consumed material, artificial food, as well as fungus. Therefore, this signal is highly conservative given the potential for background interferences. Similarly, the use of a hygromycin-resistant strain of $A$. sydowii also allowed us to track pathogen propagules, and offered the additional advantage of assessing the viability of the ingested fungus. For pathogens where genetic engineering of antimicrobial resistance (or similar genetic markers) is not feasible, the use of isotopically labeled pathogens is a viable alternative, and if partial digestion occurs, can provide a quantitative measure of the amount of undigested fungal tissue passing through the gut. If sufficient fecal matter had accumulated during the course of the experiment, the isotopically enriched fungi could also be used to determine viability. These methods are useful alternatives to microscopic or molecular techniques to detect the successful gut passage of specific species or strains of fungi (Dromph 2001, Colgan \& Claridge 2002, Meier et al. 2002, Malaquias et al. 2004, Prom \& Lopez 2004, Lilleskov \& Bruns 2005).

The results of the food choice experiment, although not statistically significant, suggest that Cyphoma gibbosum prefer diseased sea fans (Fig. 1), corroborating previous observations of an increased density of $C$. gibbosum on diseased octocorals (Nagelkerken et al. 1997a, Slattery 1999). This indicates that the fungal pathogen Aspergillus sydowii may affect non-host species by altering the feeding preference of predators.
One possible mechanism for the shift in host preference is a reduction in feeding deterrents in diseased sea fans, potentially resulting from a trade-off by corals between antifungal and anti-predator defenses. A reduction in the anti-predator defense metabolite julieannafuran in sea fans following infection by aspergillosis has been demonstrated to increase the palatability of corals to generalist omnivorous fish (Slattery 1999).

The shift in feeding behavior as a result of disease is likely to be compounded by the change in host availability due to infection-related mortality. Aspergillosis is known to infect up to 8 species of octocorals (Smith \& Weil 2004), including many of the preferred coral hosts of Cyphoma gibbosum (Eunicea, Gorgonia, Pseudopterogorgia, and Plexaura; Birkeland \& Gregory 1975, Harvell \& Suchanek 1987, Lasker \& Coffroth 1988, Lasker et al. 1988, Chiappone et al. 2003, K. Rypien unpubl.). Hence, the removal of preferred food sources due to infection will undoubtedly result in altered feeding and oviposition behavior. Given the large effects of aspergillosis on just one of its host species (causing the loss of $>50 \%$ of Florida sea fan tissue between 1997 and 2002; Kim \& Harvell 2004), aspergillosis can dramatically shift the available host community for specialist predators such as C. gibbosum.

If Cyphoma gibbosum is acting as a vector for aspergillosis, it is likely not the sole method of transmission, similar to observations in other coral pathosystems (Antonius \& Riegl 1997, Sussman et al. 2003, Williams \& Miller 2005). Evidence of multiple methods of transmission was suggested by an examination of spatial patterns of aspergillosis (Jolles et al. 2002). In fact, the patchy distribution of C. gibbosum (Birkeland \& Gregory 1975, Hazlett \& Bach 1982, Harvell \& Suchanek 1987, Lasker \& Coffroth 1988, Botero 1990, Chiappone et al. 2003) precludes it from being the sole mechanism of transmission for this disease. However, the regular feeding and mate-searching movements of this snail among a diversity of coral hosts (Gerhart 1986, Lasker et al. 1988, Nowlis 1993) suggests that a positive feedback loop may occur: once disease is present at a site, snails can spread it among corals, leading to a rapid increase in prevalence, which results in an increased likelihood of snails feeding on infected corals. In addition, the observed passage time of ingested food (approximately $2 \mathrm{~d}$ ) is similar to the frequency of individual snail movements among corals (every $3 d_{i} K$. Rypien unpubl.). The role of injury due to grazing behavior may also facilitate infection by allowing the fungus to penetrate some of the external host defenses. Fungal hyphae are rarely observed in the tissue of sea fans, and are almost exclusively seen inside the inert (non-cellular) skeleton (Mullen et al. 2004). This suggests that host defenses may provide a sub- 
stantial barrier to fungal proliferation in the sea fan tissue, and that injury due to grazing could allow for more successful fungal infections.

The role of Cyphoma gibbosum in increasing the rate of disease spread on local scales may be particularly important at sites with low external pathogen inputs or low host density, as a small number of pathogen propagules could have a larger effect than if they were spread by currents or secondary contact alone. Recent work suggests that the removal of top predators due to over-fishing may allow the release of C. gibbosum, leading to a large increase in octocoral damage due to grazing (Burkepile \& Hay 2007). This suggests that sites with reduced top predator densities may be particularly susceptible to vectored disease transmission.

Infectious disease is a component of all natural ecosystems, and pathogens interact with numerous species beyond just their host. This study demonstrates the utility of 2 methods of pathogen labeling (isotopically and antifungal resistance) to track the movement of propagules through a microbially rich environment. In addition, this study also provides evidence that the infection of Caribbean octocorals with Aspergillus sydowii may affect the behavior of specialist gastropod predators, such as Cyphoma gibbosum. The potential vectoring capability of $C$. gibbosum may help to explain spatial and temporal patterns of disease prevalence. Given the strong role of environmental drivers in exacerbating the prevalence and severity of aspergillosis (Alker et al. 2001, Bruno et al. 2003, Kim et al. 2006, Baker et al. 2007, Ward et al. 2007) and the potential for climate change to alter the distribution and life cycle of terrestrial vectors (Harvell et al. 2002), a more holistic view of the interactions between pathogens such as $A$. sydowii and non-host species in the community is vital for predicting and mitigating future disease outbreaks.

Acknowledgements. We thank the Harvell laboratory, K. Kim, and the staff of the Cornell University Stable Isotope Lab for laboratory support and advice, Tom's Caribbean Tropicals Inc. for snail collection, and the staff at the Perry Institute for Marine Science, Caribbean Marine Research Center. Thanks to 2 anonymous reviewers for their comments. This work was funded by an Andrew W. Mellon student research grant (K.L.R.), a Teresa Heinz Scholar for Environmental Research grant (K.L.R.), a Mario Einaudi International Research Travel Grant (K.L.R.), an EPA-STAR fellowship (D.M.B.), and a Sigma Xi Research grant (K.L.R.).

\section{LITERATURE CITED}

Alker AP, Smith GW, Kim K (2001) Characterization of Aspergillus sydowii (Thom et Church), a fungal pathogen of Caribbean sea fan corals. Hydrobiologia 460:105-111
Anderson PK, Cunningham AA, Patel NG, Morales FJ, Epstein PR, Daszak P (2004) Emerging infectious diseases of plants: pathogen pollution, climate change and agrotechnology drivers. Trends Ecol Evol 19:535-554

Antonius A, Riegl B (1997) A possible link between coral diseases and a corallivorous snail (Drupella cornus) outbreak in the Red Sea. Atoll Res Bull 447:2-9

Antonovics J, Iwasa Y, Hassell MP (1995) A generalized model of parasitoid, venereal and vector-based transmission processes. Am Nat 145:661-675

Baker DM, MacAvoy SE, Kim K (2007) Relationship between water quality, $\delta^{15} \mathrm{~N}$, and aspergillosis of Caribbean sea fan corals. Mar Ecol Prog Ser 343:123-130

Birkeland C, Gregory B (1975) Foraging behavior and rates of feeding of the gastropod, Cyphoma gibbosum. Bull Nat Hist Mus Los Angeles 20:57-67

Botero L (1990) Observations on the size, predators and tumor-like outgrowths of gorgonian octocoral colonies in the area of Santa Marta, Caribbean coast of Colombia. Northeast Gulf Sci 11:1-10

Bruno JF, Petes LE, Harvell CD, Hettinger A (2003) Nutrient enrichment can increase the severity of coral diseases. Ecol Lett 6:1056-1061

Burkepile DE, Hay ME (2007) Predator release of the gastropod Cyphoma gibbosum increases predation on gorgonian corals. Oecologia 154:167-173

Chiappone M, Dienes H, Swanson DW, Miller SL (2003) Density and gorgonian host-occupation patterns by flamingo tongue snails (Cyphoma gibbosum) in the Florida Keys. Caribb J Sci 39:116-127

Colgan W III, Claridge AW (2002) Mycorrhizal effectiveness of Rhizopogon spores recovered from faecal pellets of small forest-dwelling mammals. Mycol Res 106:314-320

Dobson A (2004) Population dynamics of pathogens with multiple host species. Am Nat 164:S64-S78

Domsch KH, Gams W, Anderson TH (1980) Compendium of soil fungi. Academic Press, London

> Dromph KM (2001) Dispersal of entomopathogenic fungi by collembolans. Soil Biol Biochem 33:2047-2051

Ewald PW (1983) Host-parasite relations, vectors, and the evolution of disease severity. Annu Rev Ecol Syst 14: 465-485

Gardner TA, Côte IM, Gill JA, Grant A, Watkinson AW (2003) Long-term region-wide declines in Caribbean corals. Science 301:958-960

Gerhart DJ (1986) Gregariousness in the gorgonian-eating gastropod Cyphoma gibbosum: tests of several possible causes. Mar Ecol Prog Ser 31:255-263

Grajales A, Aguilar C, Sánchez JA (2007) Phylogenetic reconstruction using secondary structures of Internal Transcribed Spacer 2 (ITS2, rDNA): finding the molecular and morphological gap in Caribbean gorgonian corals. BMC Evol Biol 7:90

> Harvell CD, Suchanek TH (1987) Partial predation on tropical gorgonians by Cyphoma gibbosum (Gastropoda). Mar Ecol Prog Ser 38:37-44

> Harvell CD, Mitchell CE, Ward JR, Altizer S, Dobson AP, Ostfeld RS, Samuel MD (2002) Climate warming and disease risks for terrestrial and marine biota. Science 296:2158-2162

> Harvell D, Aronson R, Baron N, Connell J and others (2004) The rising tide of ocean diseases: unsolved problems and research priorities. Front Ecol Environ 2:375-382

Harvell D, Jordán-Dahlgren E, Merkel S, Rosenberg E and others (2007) Coral disease, environmental drivers, and the balance between coral and microbial associates. Oceanography (Wash DC) 20:172-195 
Hatcher MJ, Dick JTA, Dunn AM (2006) How parasites affect interactions between competitors and predators. Ecol Lett 9:1253-1271

Hazlett BA, Bach CE (1982) Distribution pattern of the flamingo tongue shell (Cyphoma gibbosum) on its gorgonian prey (Briareum asbestinum). Mar Behav Physiol 8: 305-309

Hoegh-Guldberg O (1999) Climate change, coral bleaching and the future of the world's coral reefs. Mar Freshw Res 50:839-866

Hughes TP, Baird AH, Bellwood DR, Card M and others (2003) Climate change, human impacts, and the resilience of coral reefs. Science 301:929-933

Jolles AE, Sullivan P, Alker AP, Harvell CD (2002) Disease transmission of aspergillosis in sea fans: inferring process from spatial pattern. Ecology 83:2373-2378

Keesing F, Holt RD, Ostfeld RS (2006) Effects of species diversity on disease risk. Ecol Lett 9:485-498

Kim K, Harvell CD (2004) The rise and fall of a six-year coralfungal epizootic. Am Nat 164:S52-S63

Kim K, Alker AP, Shuster K, Quirolo C, Harvell CD (2006) Longitudinal study of aspergillosis in sea fan corals. Dis Aquat Org 69:95-99

Klich MA (2002) Identification of common Aspergillus species. Centraalbureau voor Schimmelcultures, Utrecht

Lasker HR, Coffroth MA (1988) Temporal and spatial variability among grazers: variability in the distribution of the gastropod Cyphoma gibbosum on octocorals. Mar Ecol Prog Ser 43:285-295

Lasker HR, Coffroth MA, Fitzgerald LM (1988) Foraging patterns of Cyphoma gibbosum on octocorals: the roles of host choice and feeding preference. Biol Bull 174:254-266

Lilleskov EA, Bruns TD (2005) Spore dispersal of a resupinate ectomycorrhizal fungus, Tomentella sublilacina, via soil food webs. Mycologia 97:762-769

Malaquias MAE, Condinho S, Cervera JL, Sprung M (2004) Diet and feeding biology of Haminoea orbygniana. J Mar Biol Assoc UK 84:767-772

McCallum H, Harvell D, Dobson A (2003) Rates of spread of marine pathogens. Ecol Lett 6:1062-1067

Meier FA, Scherrer S, Honegger R (2002) Faecal pellets of lichenivorous mites contain viable cells of the lichen-forming ascomycete Xanthoria parietina and its green algal photobiont, Trebouxia arboricola. Biol J Linn Soc 76 : 259-268

Mullen KM, Peters EC, Harvell CD (2004) Coral resistance to disease. In: Rosenberg E, Loya Y (eds) Coral health and

Editorial responsibility: Mike Hine,

Fouras, France disease. Springer-Verlag, New York, p 377-400

Nagelkerken I, Buchan K, Smith GW, Bonair K and others (1997a) Widespread disease in Caribbean sea fans: II. Patterns of infection and tissue loss. Mar Ecol Prog Ser 160:255-263

Nagelkerken I, Buchan K, Smith GW, Bonair K and others (1997b) Widespread disease in Caribbean sea fans: I. Spreading and general characteristics. Proc 8th Int Coral Reef Symp 1:679-682

Nowlis JP (1993) Mate- and oviposition-influenced host preferences in the coral-feeding snail Cyphoma gibbosum. Ecology 74:1959-1969

Opresko DM (1973) Abundance and distribution of shallowwater gorgonians in the area of Miami, Florida. Bull Mar Sci 23:535-558

> Patterson KL, Porter JW, Ritchie KB, Polson SW and others (2002) The etiology of white pox, a lethal disease of the Caribbean elkhorn coral, Acropora palmata. Proc Natl Acad Sci USA 99:8725-8730

> Prom LK, Lopez JD Jr (2004) Viability of Claviceps africana spores ingested by adult corn earworm moths, Helicoverpa zea (Boddie) (Lepidoptera: Noctuidae). J Econ Entomol 97:764-767

Slattery M (1999) Fungal pathogenesis of the sea fan Gorgonia ventalina: direct and indirect consequences. Chemoecology 9:97-104

Smith GW, Weil E (2004) Aspergillosis of gorgonians. In: Rosenberg E, Loya Y (eds) Coral health and disease. Springer-Verlag, New York, p 279-288

Smith GW, Ives LD, Nagelkerken IA, Ritchie KB (1996) Caribbean sea-fan mortalities. Nature 383:487

St. Germain G, Summerbell R (1996) Identifying filamentous fungi: a clinical laboratory handbook. Star Publishing, Belmont, CA

Sussman M, Loya Y, Fine M, Rosenberg E (2003) The marine fireworm Hermodice carunculata is a winter reservoir and spring-summer vector for the coral-bleaching pathogen Vibrio shiloi. Environ Microbiol 5:250-255

Ward JR, Lafferty KD (2004) The elusive baseline of marine disease: Are diseases in ocean ecosystems increasing? PLoS Biol 2:542-547

Ward JR, Kim K, Harvell CD (2007) Temperature affects coral disease resistance and pathogen growth. Mar Ecol Prog Ser 329:115-121

- Williams DE, Miller MW (2005) Coral disease outbreak: pattern, prevalence and transmission in Acropora cervicornis. Mar Ecol Prog Ser 301:119-128

Submitted: February 11, 2009; Accepted: June 24, 2009 Proofs received from author(s): August 28, 2009 